\title{
Synthesis, spectroscopic characterization and DFT calculations of a new highly fluorescent heterocyclic system: imidazo[4,5-a]quinindoline
}

\author{
Mina Sokhanvar and Mehdi Pordel* \\ Department of Chemistry, College of Science, Mashhad Branch, Islamic Azad University, \\ Mashhad, Iran \\ E-mail: mehdipordel58@,mshdiau.ac.ir
}

DOI: http://dx.doi.org/10.3998/ark.5550190.p008.597

\begin{abstract}
New N-alkyl-substituted heterocyclic system imidazo[4,5-a]quinindolines (imidazo[4,5-f]indolo[2,3-b]quinolines) were synthesized by one pot reaction of 1-alkyl-5-nitro-1Hbenzimidazole with 2-(1-alkyl-1H-3-indolyl)acetonitrile in basic media via the nucleophilic substitution of hydrogen and concomitant cyclisation in good yields. Physical spectral (UV-vis, IR, NMR and fluorescence) and analytical data have established the structures of synthesized compounds. The fluorescence properties of these new heterocyclic compounds were studied. The fluorescence of all compounds was very intense and fluorescence quantum yields were very high $(>0.70)$. Solvent effects on absorption and emission spectra of these dyes have also been studied; the absorption and emission bands in polar solvents undergo a red shift. Density function theory (DFT) calculations of one structure by using the B3LYP hybrid functional and the $6-311+\mathrm{G}(\mathrm{d}, \mathrm{p})$ basis set to provide the relevant frontier orbitals were also performed.
\end{abstract}

Keywords: Nucleophilic substitution of hydrogen; imidazo[4,5-a]quinindoline; fluorescence; emission and absorption spectra; DFT calculations

\section{Introduction}

Nitrogen fluorescent heterocyclic compounds are of special interest, because they exhibit unique electrical and optical properties such as emitters for electroluminescence devices, ${ }^{1}$ molecular probes for biochemical research, ${ }^{2}$ in traditional textile and polymer fields, ${ }^{3}$ fluorescent whitening agents ${ }^{4}$ and photo conducting materials. ${ }^{5}$ Naturally occurring substituted imidazoles, as well as synthetic derivatives thereof, exhibit wide ranges of biological activities and optical applications such as fluorescence compounds, dyes, and TPA (Two-photon absorption) materials ${ }^{6-8}$ making them attractive compounds for organic chemists. Also, many commercial fluorescent brighteners for application to synthetic fibers contain an imidazole moiety. ${ }^{9}$ 
On the other hand, indoloquinoline alkaloids have recently received considerable attention due to their promising DNA intercalating ${ }^{10}$ and antimalarial properties. ${ }^{11-13}$ Particularly, indolo[2,3- $b$ ]quinolines (also called quinindolines), are a group of synthetic analogues of the natural alkaloid neocryptolepine. They share many biological properties with this compound, including the ability to interact with DNA as intercalators and to inhibit topoisomerase II reactivity. The quinindoline derivatives also revealed antimicrobial, antimuscarinic, antiviral, and cytotoxic potential. ${ }^{14-16}$ A combination of the quinindoline moiety with the imidazole nucleus may enhance optical and biological properties.

Based on these aspects and in continuation with our research work on the efficient synthesis of new dyes and fluorescent nitrogen heterocyclic compounds, ${ }^{17-23}$ we examined the transformation of 1-alkyl-5-nitro- $1 H$-benzoimidazole with 2-(1-alkyl-1H-3-indolyl)acetonitrile to new fluorescent heterocyclic system imidazo[4,5-a]quinindoline via the nucleophilic substitution of hydrogen. ${ }^{24,25}$ The fluorescence properties of these new heterocyclic compounds and DFT calculations of one structure by using the B3LYP hybrid functional and the 6$311+\mathrm{G}(\mathrm{d}, \mathrm{p})$ basis set have also been studied.

\section{Results and discussion}

\section{Synthesis and Structures of the new compounds 3a-d}

The treatment of 1-alkyl-5-nitro-1H-benzoimidazoles 1a,b with 2-(1-alkyl-1H-3indolyl)acetonitriles 2a,b led to the formation of the new 3-alkyl-7-alkyl-3,7dihydroimidazo[4,5-a]quinindoline-12-carbonitriles 3a-d in basic $\mathrm{MeOH}$ solution via the nucleophilic substitution of hydrogen, ${ }^{24,25}$ which proceeded at room temperature with subsequent cyclisation and in good yields (Scheme 1). One of the noteworthy points in this reaction was the simple work-up procedure performed by filtration of the precipitated product after the mixture was concentrated at reduced pressure. Washing the precipitated product with suitable solvents (water and then acetone) gives practically pure compounds 3a-d.

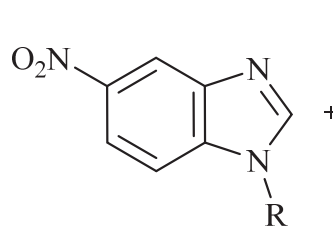

$1 \mathbf{a}, \mathbf{b}$

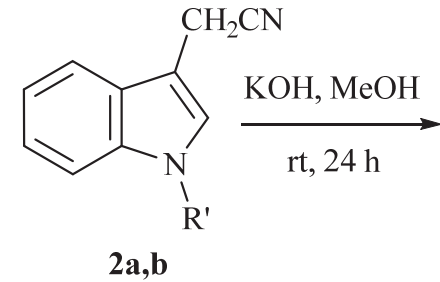

$\mathbf{2 a , b}$<smiles></smiles>

3a-d 3a: $\mathrm{R}=\mathrm{Me}, \mathrm{R}^{\prime}=\mathrm{Me}(60 \%)$ 3b: $\mathrm{R}=\mathrm{Me}, \mathrm{R}^{\prime}=\mathrm{Et}(74 \%)$ 3c: $R=\operatorname{Pr}, R^{\prime}=\operatorname{Me}(70 \%)$ 3d: $\mathrm{R}=\operatorname{Pr}, \mathrm{R}^{\prime}=\mathrm{Et}(75 \%)$

Scheme 1. Synthesis of new compounds 3a-d 
In the following mechanism ${ }^{17-23}$ the ring closure proceeds via an electrocyclic pathway, wherein intermediate $\mathrm{B}$ is converted into $\mathrm{C}$ followed by loss of one $\mathrm{H}_{2} \mathrm{O}$ molecule, whereupon compounds 3a-d are obtained (Scheme 2).

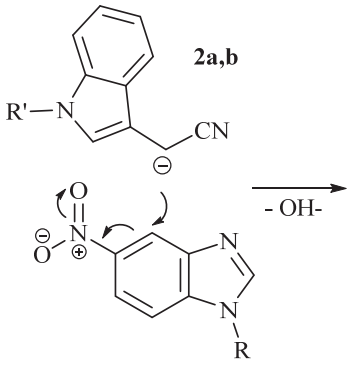

$\mathbf{1 a}, \mathbf{b}$

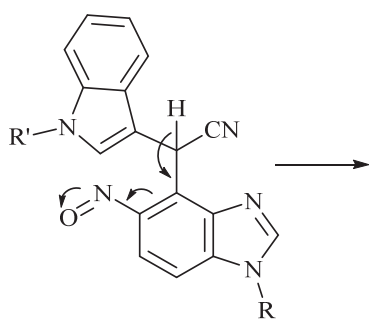

A

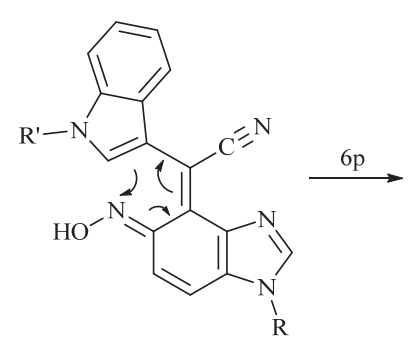

B

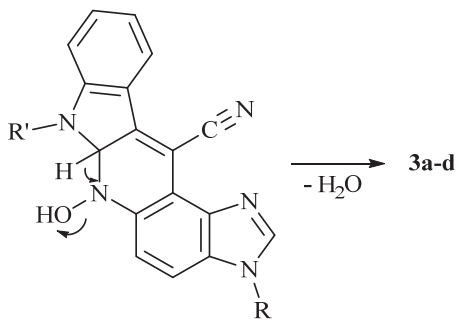

C

Scheme 2. Proposed reaction mechanism for the formation of compounds 3a-d

The structures of the pentacyclic products 3a-d were confirmed by NMR techniques, IR spectroscopy, mass spectral and microanalytical data. The spectral details of all these are given in the Experimental section. For example, there are two triplet of doublet signals at $\delta=7.43$ and $7.73 \mathrm{ppm}$ and two doublet signals $(\delta=7.55$ and $8.95 \mathrm{ppm})$ can be attributed to A ring, two doublet peaks at $\delta=7.87$ and $8.11 \mathrm{ppm}$ assignable to two protons of $\mathrm{D}$ aromatic ring and a singlet peak at $\delta=8.21 \mathrm{ppm}$ correspond to $\mathrm{E}$ ring in the ${ }^{1} \mathrm{H}$ NMR spectrum of compound $3 \mathbf{d}$ in the expanded aromatic region (Figure 1). Also, there are 22 different carbon atoms in the ${ }^{13} \mathrm{C}$ NMR spectrum of compound 3d. Moreover, the FT-IR spectrum of 3d in $\mathrm{KBr}$ showed an absorption band at $2223 \mathrm{~cm}^{-1}$ corresponding to the cyano group. All this evidence plus molecular ion peak at $m / z 353\left(\mathrm{M}^{+}\right)$and microanalytical data strongly support the pentacyclic structure of compound 3d. 


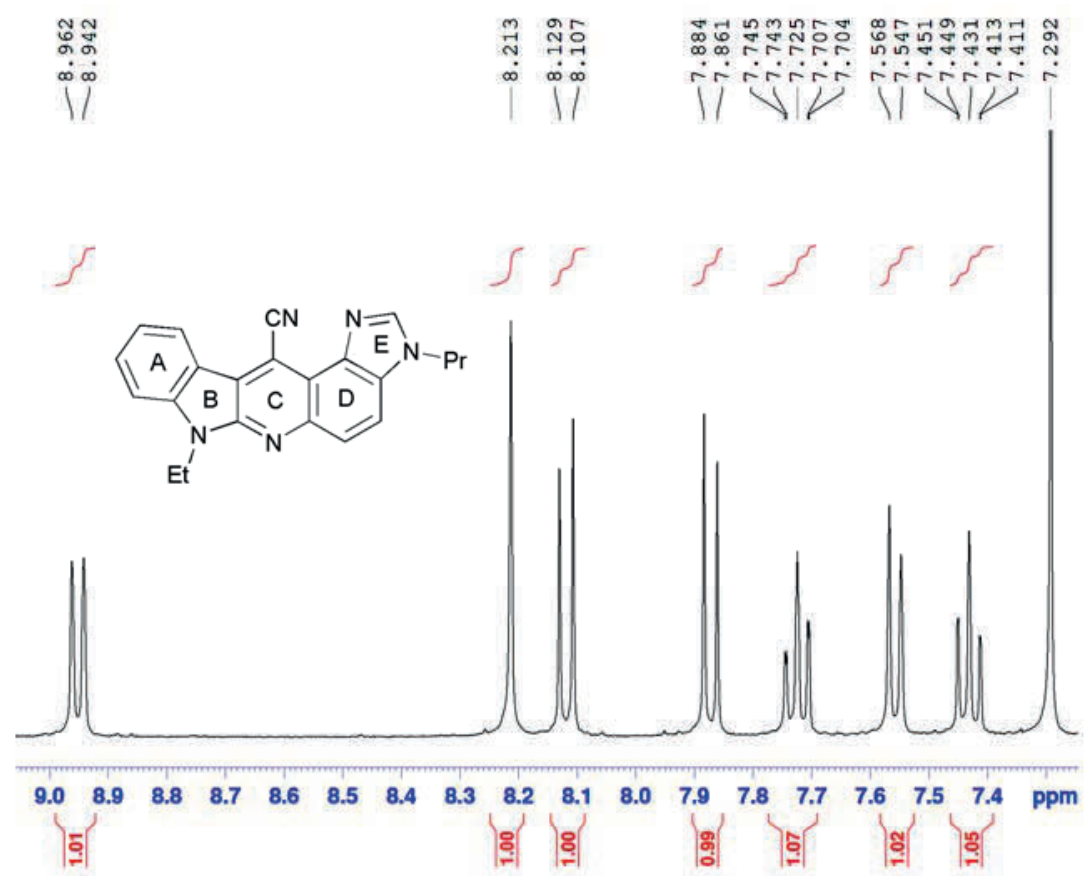

Figure 1. Expanded view (aromatic region) of the proton NMR spectrum of compound 3d.

\section{Fluorescent activity}

The compounds 3a-d were spectrally characterized by using an UV-Vis spectrophotometer and a fluorescence spectrophotometer. The wavelength range of both spectrophotometers is $200 \mathrm{~nm}$ $1000 \mathrm{~nm}$. The fluorescence absorption and emission spectra of 3a-d were recorded at concentrations of $1 \times 10^{-6}$ and $3 \times 10^{-7} \mathrm{~mol} \mathrm{~L}^{-1}$ in dichloromethane (DCM), respectively. Numerical data are presented in Table 1; Figures 2 and 3 show the visible absorption and emission spectra of compounds $\mathbf{3 a - d}$.

Table 1. Photophysical data for absorption (abs) and fluorescence (flu) of 3a-d

\begin{tabular}{lllll}
\hline Dye & 3a & 3b & 3c & 3d \\
\hline$\lambda_{\text {abs }}(\mathrm{nm})^{a}$ & 371 & 373 & 373 & 375 \\
$\varepsilon \times 10^{-4}\left[\left(\mathrm{~mol} \mathrm{~L}^{-1}\right)^{-1} \mathrm{~cm}^{-1}\right]^{b}$ & 92 & 95 & 84 & 81 \\
$\lambda_{\text {ex }}(\mathrm{nm})^{c}$ & 400 & 400 & 400 & 400 \\
$\lambda_{\text {flu }}(\mathrm{nm})^{d}$ & 484 & 476 & 476 & 473 \\
$\Phi_{\mathrm{F}}{ }^{e}$ & 0.71 & 0.77 & 0.80 & 0.85 \\
\hline
\end{tabular}

${ }^{a}$ Wavelengths of maximum absorbance; ${ }^{b}$ Extinction coefficient; ${ }^{c}$ Wavelengths of fluorescence excitation; ${ }^{d}$ Wavelengths of fluorescence emission; ${ }^{e}$ Fluorescence quantum yield. 
Values of extinction coefficient $(\varepsilon)$ were calculated as the slope of the plot of absorbance $v s$ concentration. The fluorescence excitation $\left(\lambda_{\text {ex }}\right)$ wavelength at $400 \mathrm{~nm}\left(\lambda_{\text {ex }} / \mathrm{nm}\right)$ was used for all compounds 3a-d. The fluorescence quantum yields $\left(\Phi_{\mathrm{F}}\right)$ of compounds 3a-d were determined via comparison methods, using fluorescein as a standard sample in $0.1 \mathrm{M} \mathrm{NaOH}$ and $\mathrm{MeOH}$ solution. ${ }^{26}$ The used value of the fluorescein emission quantum yield is 0.79 . The absorbance and fluorescence spectral properties (Table 1) of compounds 3a-d are similar to each other and the fluorescence quantum yield in compound 3d $\left(R=\operatorname{Pr}, R^{\prime}=E t\right)$ was the highest.

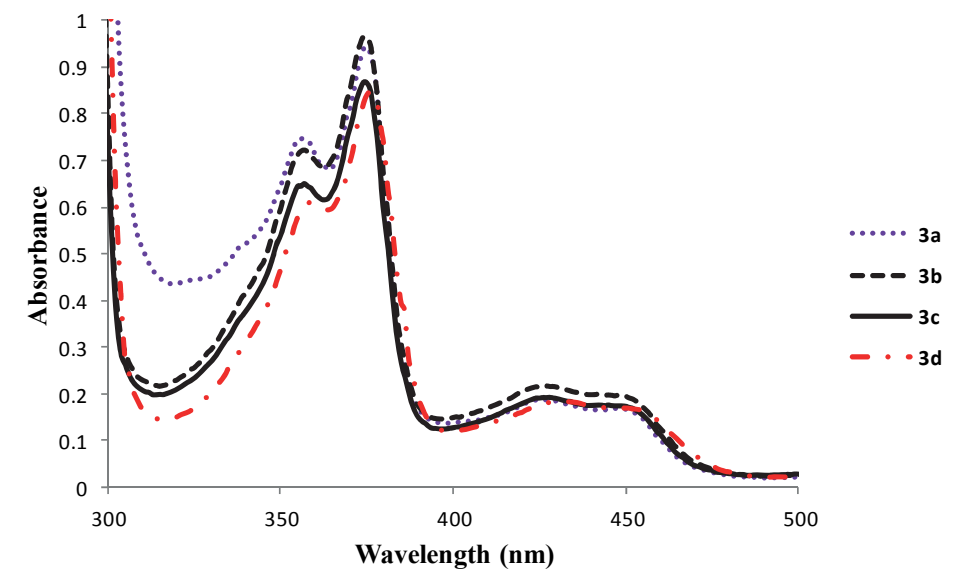

Figure 2. Visible absorption spectra of compounds 3a-d in DCM solution $\left(1 \times 10^{-6} \mathrm{~mol} \mathrm{~L}^{-1}\right)$.

The fluorescence intensity in these compounds can be explained by an efficient intramolecular charge transfer (ICT) states from the donor site (endocyclic N) to the acceptor moiety (CN group). ${ }^{17-22}$ In Scheme 3 neutral and some charge-separated mesomeric structures of 3a-d are presented. As seen in this scheme, there are two nitrogen donors which can explain the shoulder on the right side of the peaks in emission spectra of compounds 3a-d (Figure 3).

The fluorescence quantum yield $\left(\Phi_{\mathrm{F}}\right)$ of the new compound $\mathbf{3 d}$ is comparable with some of the fluorescent heterocyclic compounds which we have previously synthesized. A comparison of $\Phi_{\mathrm{F}}$ and $\lambda_{\text {flu }}$ between $\mathbf{3 d}$ and some of these is shown in Table 2.

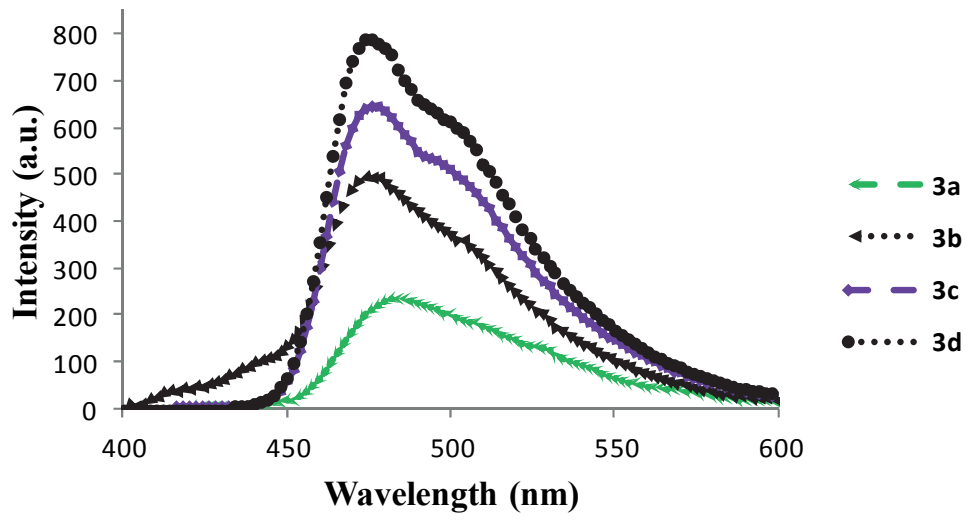

Figure 3. Emission spectra of compounds 3a-d in DCM solution $\left(3 \times 10^{-7} \mathrm{~mol} \mathrm{~L}^{-1}\right)$. 


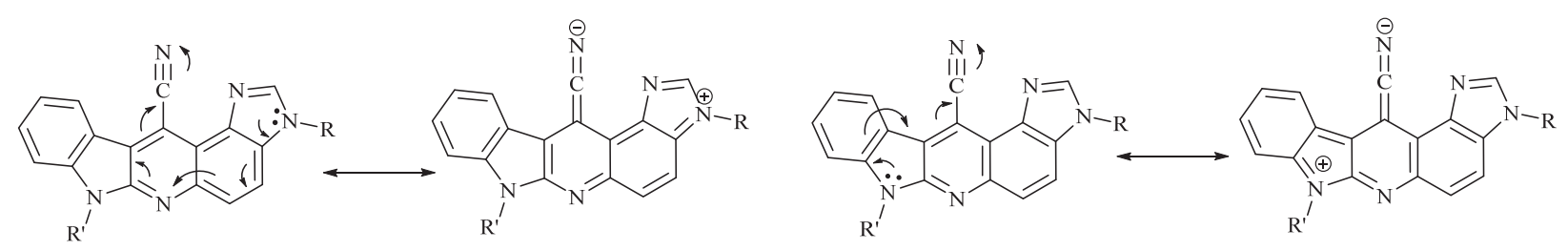

Scheme 3. Neutral and some charge-separated mesomeric structures of 3a-d.

Table 2. Comparison of the $\Phi_{\mathrm{F}}$ and $\lambda_{\text {flu }}$ of $\mathbf{3 d}$ and some recently synthesized fluorescent heterocyclic compounds

(n)

Solvatochromic properties of compound 3c were studied in some solvents (Figs. 4 and 5). As it is depicted in these figures, the fluorescence absorption and particularly emission spectra of 3c in polar solvents undergo a red shift. Increasing solvent polarity stabilizes the ICT excited-state molecule relative to the ground-state molecule with the observed red shift of the absorption and emission maximums as the experimentally observed result (Table 3 ). For example, $\lambda_{\text {flu }}$ shifts from 465 to $495 \mathrm{~nm}$ is observed as the solvent is changed from toluene to methanol.

Table 3. Spectroscopic data for $\mathbf{3 c}$ at $298 \mathrm{~K}$ in dependence of the solvent

\begin{tabular}{lll}
\hline Solvent & $\lambda_{\text {abs }}(\mathrm{nm})$ & $\lambda_{\text {flu }}(\mathrm{nm})$ \\
\hline Toluene & 372 & 465 \\
Ethyl acetate & 374 & 471 \\
DMF & 377 & 480 \\
Acetonitrile & 376 & 477 \\
Methanol & 380 & 495 \\
\hline
\end{tabular}




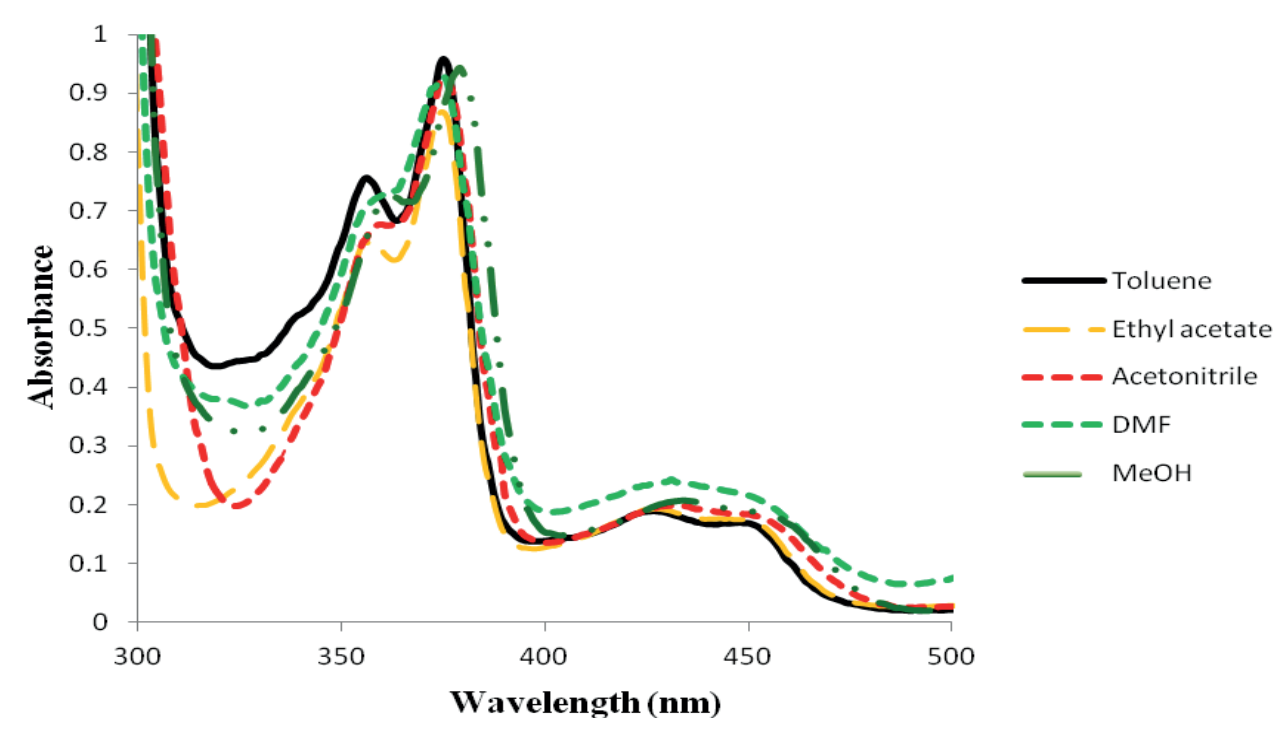

Figure 4. Visible absorption spectra of compound $\mathbf{3 c}$ in different solvents $\left(1 \times 10^{-6} \mathrm{~mol} \mathrm{~L}^{-1}\right)$.

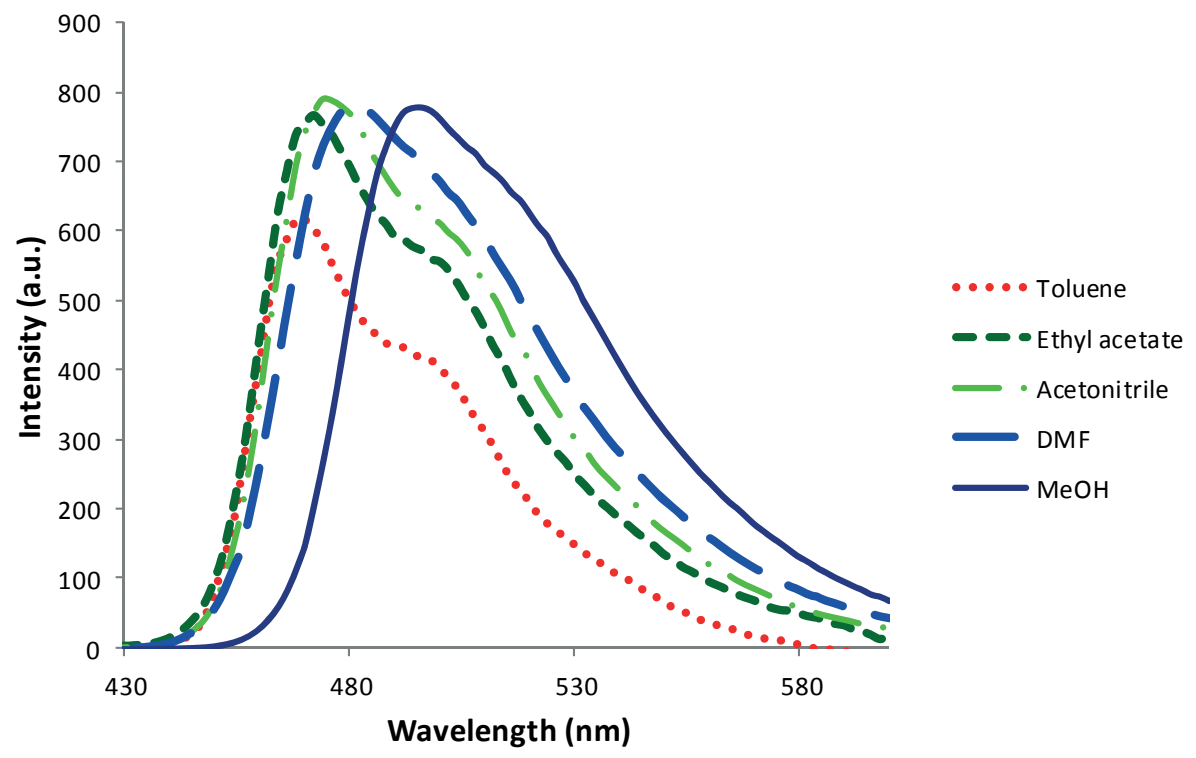

Figure 5. Emission spectra of compound $3 \mathbf{c}$ in some solvents $\left(5 \times 10^{-7} \mathrm{~mol} \mathrm{~L}^{-1}\right)$.

\section{DFT calculations}

The optimized geometry of compound 3a is shown in Figure 6. In the optimized geometry of the 3a, all of these rings and cyano group are essentially planar and the $\mathrm{C}=\mathrm{C}$ bond lengths (1.38-1.44 Ångstrom) of the aromatic rings are in the expected range (Table S1; see Supplementary data). ${ }^{27}$ 


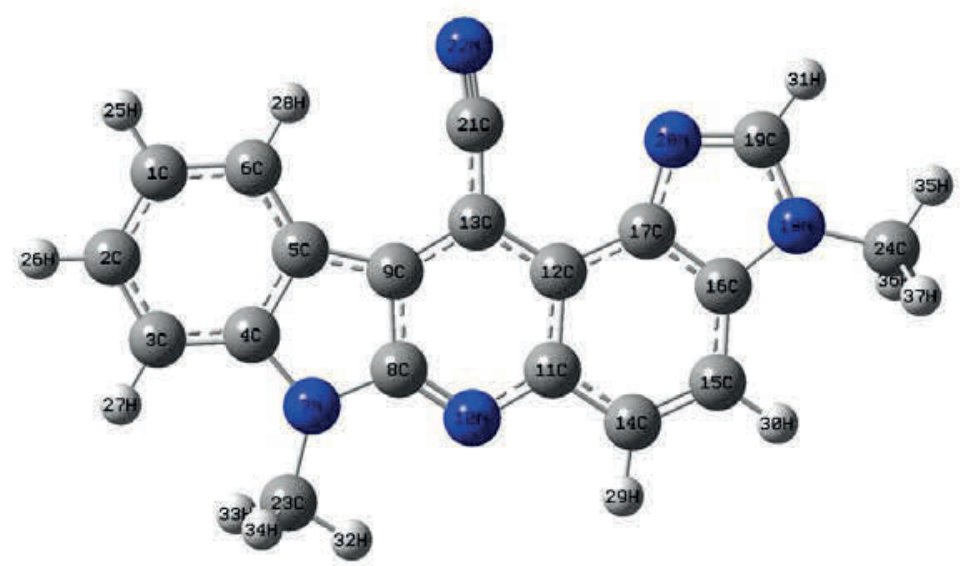

Figure 6. Optimized geometry of the compound 3a.

As seen in Table 4, the DFT calculated chemical shifts $(\delta)$ of the compound 3a are well in agreement with the experimental values, confirming validity of the optimized geometry as a proper structure for $\mathbf{3 a}$.

Table 4. Experimental and DFT calculated ${ }^{1} \mathrm{H}$ NMR chemical shifts of compound 3a

\begin{tabular}{ccccccc}
\hline \multirow{2}{*}{ Atom number } & \multicolumn{2}{c}{ Chemical shift } & \multirow{2}{*}{ A tom number } & \multicolumn{2}{c}{ Chemical shift } \\
\cline { 2 - 3 } & Calc. & Exp. & & Calc. & Exp. \\
\hline H28 & 9.34 & 8.96 & H27 & 7.44 & 7.46 \\
H29 & 8.11 & 8.09 & H32 & 5.20 & 4.27 \\
H30 & 7.83 & 7.89 & H35 & 3.84 & 4.05 \\
H31 & 7.82 & 8.22 & H36 & 3.84 & 4.05 \\
H26 & 7.73 & 7.71 & H37 & 3.84 & 4.05 \\
H25 & 7.52 & 7.57 & H33, H34 & 3.36 & 4.27 \\
\hline
\end{tabular}

The energy difference between the HOMO and LUMO frontier orbitals is one of the important characteristics of molecules, which has a determining role in such cases as electric properties, electronic spectra and photochemical reactions. The HOMO and LUMO maps of 3a are shown in Fig. 7. It shows that the frontier molecular orbitals of $\mathbf{3 a}$ are mainly composed of $p$ atomic orbital, so electronic transition corresponds to above electronic spectra are due to $\pi-\pi^{*}$ electronic transitions. Energy separation between the HOMO and LUMO is $3.45 \mathrm{eV}$ (359.4 nm). As seen; the HOMO and LUMO are totally delocalized because of the unsaturated nature of the system. 

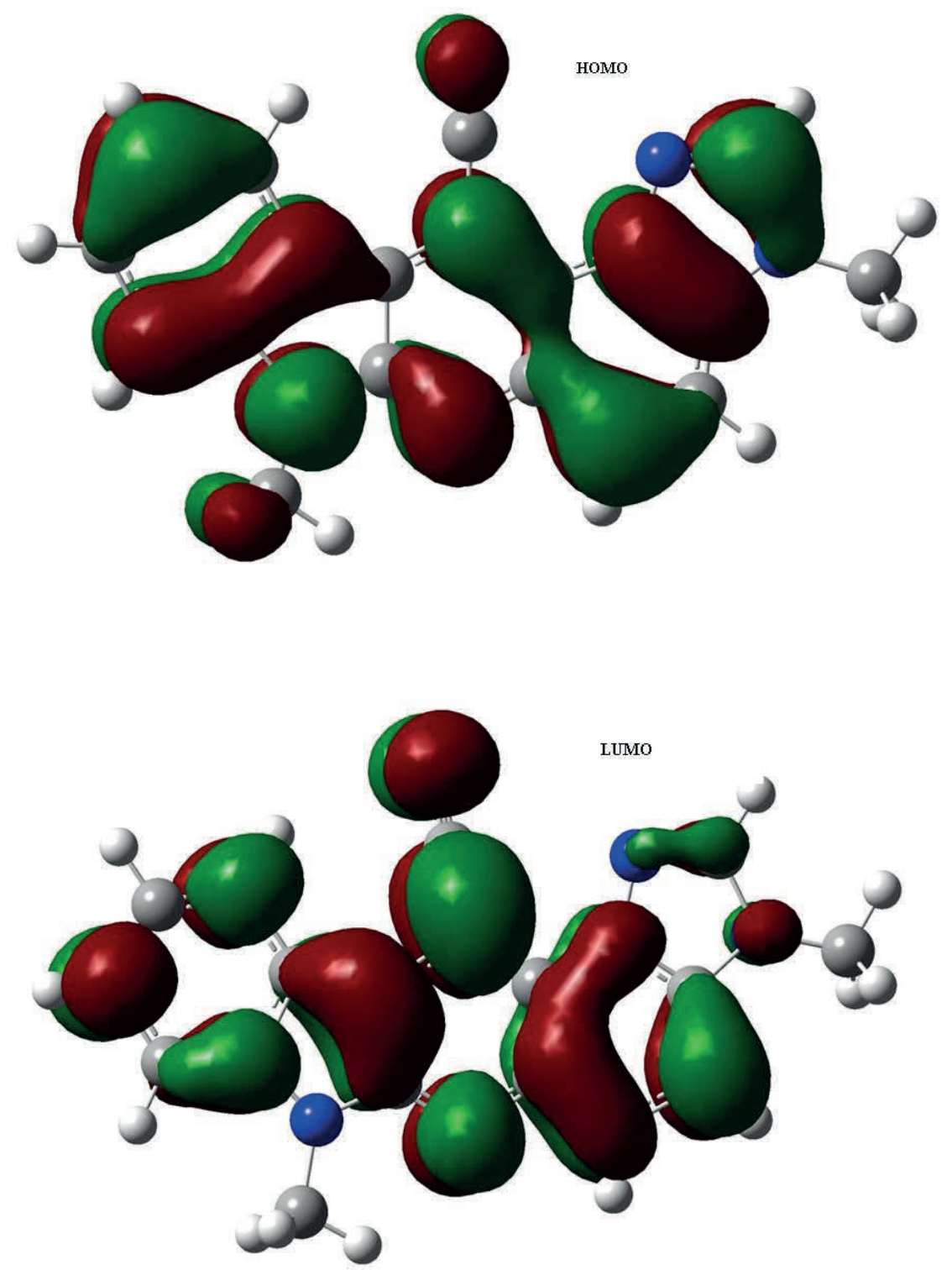

Figure 7. The HOMO and LUMO frontier orbitals of the compound 3a.

\section{Conclusions}

We have successfully synthesized and characterized a new substituted heterocyclic system imidazo[4,5-a]quinindoline by one-pot reaction of 1-alkyl-5-nitro-1H-benzoimidazole with 2-(1alkyl-1H-3-indolyl)acetonitrile in basic media. Considerable photophysical data of these dyes clearly show that they have very strong fluorescence intensities. DFT calculations to gain a deeper insight into the charge transfer properties were also performed. Because of the use of fluorescence for imaging in the biological and material science fields, further synthetic and 
fluorescence studies are necessary on similar substrates to expand this field of knowledge and establish sound conclusions. This work is in progress.

\section{Experimental Section}

\section{Materials}

Methanol, $N, N$-dimethylformamide (DMF), dichloromethane (DCM), toluene, ethyl acetate, acetonitrile, methyl iodide, ethyl bromide, n-propyl bromide, dimethylamine, formaldehyde, potassium cyanide, 5-nitro- $1 H$-benzimidazole and indole were purchased from Merck. Potassium hydroxide was purchased from Sigma-Aldrich. All solvents were dried according to standard procedures. Compounds $\mathbf{1} \mathbf{a}, \mathbf{b}^{28}$ and $\mathbf{2} \mathbf{a}, \mathbf{b}^{29,30}$ were synthesized as in the cited references.

\section{Equipment}

Absorption and fluorescence spectra were recorded on Varian Cary 50-Bio UV-visible spectrophotometer and Varian Cary Eclipse spectrofluorophotometer. UV-vis and fluorescence scans were recorded from 200 to $1000 \mathrm{~nm}$. Melting points were measured on an Electrothermal type-9100 melting-point apparatus. The IR (as KBr discs) spectra were obtained on a Tensor 27 spectrometer and only noteworthy absorptions are listed. The ${ }^{13} \mathrm{C}$ NMR $(100 \mathrm{MHz})$ and the ${ }^{1} \mathrm{H}$ NMR (400 MHz) spectra were recorded at on a Bruker Avance DRX-400 FT spectrometer in $\mathrm{CDCl}_{3}$. Chemical shifts are reported in ppm downfield from TMS as internal standard; coupling constant $J$ is given in Hz. The mass spectra were recorded on a Varian Mat, $\mathrm{CH}-7$ at $70 \mathrm{eV}$. Elemental analysis was performed on a Thermo Finnigan Flash EA microanalyzer. All measurements were carried out at room temperature.

\section{Computational methods}

DFT calculations were performed with the Gaussian 98 software package ${ }^{31}$ by using the B3LYP hybrid functional $^{32}$ and the $6-311+\mathrm{G}(\mathrm{d}, \mathrm{p})$ basis set. Firstly, geometry of the compound 3a was fully optimized in the chloroform solution. The optimized geometry was confirmed to have no imaginary frequency. Then, its optimized geometry was used for frequency calculations.

Here, one of self-consistent reaction field methods, the sophisticated Polarized Continuum Model (PCM) ${ }^{33}$ has been used for investigation of the solvent effects. The PCM calculations have been performed in the chloroform solution and the zero-point corrections were considered to obtain energies.

The ${ }^{1} \mathrm{H}$ NMR chemical shifts of the 3a were predicted with respect to tetramethylsilane (TMS). Here, the GIAO method was used for prediction of DFT nuclear shielding. ${ }^{34}$

\section{General procedure for the synthesis of 3a-d from 1a,b and $2 a, b$}

1-Alkyl-5-nitro-1H-benzimidazole 1a,b (10 mmol) and 2-(1-alkyl-1H-3-indolyl)acetonitrile 2a,b (12 mmol) were added with stirring to a solution of $\mathrm{KOH} \mathrm{(13} \mathrm{g,} 238 \mathrm{mmol})$ in methanol (50 mL). 
The mixture was stirred at $\mathrm{rt}$ for $24 \mathrm{~h}$. After concentration at reduced pressure, the precipitate was collected by filtration, washed with water, following with acetone, and then air dried to give practically pure 3a-d.

3,7-Dimethyl-3,7-dihydroimidazo[4,5-a]quinindoline-12-carbonitrile (3a): compound 3a was obtained as shiny yellow needles $(\mathrm{EtOH})$, yield $60 \%$, mp $360-362{ }^{\circ} \mathrm{C} ;{ }^{1} \mathrm{H} \mathrm{NMR}\left(\mathrm{CDCl}_{3}\right) \delta 4.05$ $(\mathrm{s}, 3 \mathrm{H}), 4.27(\mathrm{~s}, 3 \mathrm{H}), 7.46\left(\mathrm{td}, J_{1} 8.0 \mathrm{~Hz}, J_{2} 0.8 \mathrm{~Hz}, 1 \mathrm{H}\right), 7.57(\mathrm{~d}, J 8.4 \mathrm{~Hz}, 1 \mathrm{H}), 7.71\left(\mathrm{td}, J_{1} 8.0\right.$ $\left.\mathrm{Hz}, J_{2} 1.2 \mathrm{~Hz}, 1 \mathrm{H}\right), 7.89(\mathrm{~d}, J 9.2 \mathrm{~Hz}, 1 \mathrm{H}), 8.09$ (d, J $\left.9.2 \mathrm{~Hz}, 1 \mathrm{H}\right), 8.22(\mathrm{~s}, 1 \mathrm{H}), 8.96(\mathrm{~d}, J 8.0 \mathrm{~Hz}$, 1H) ppm; ${ }^{13} \mathrm{C}$ NMR $\left(\mathrm{CDCl}_{3}\right): \delta$ 31.1, 35.0, 104.2, 108.9, 113.2, 115.9, 117.7, 118.2, 119.1, $120.2,124.87,124.92,129.6,129.9,137.8,141.7,142.2,144.3,149.6$ ppm; IR (KBr disk): $v$ $2223 \mathrm{~cm}^{-1}(\mathrm{CN})$. MS (m/z) $311\left(\mathrm{M}^{+}\right)$. Anal. Calcd for $\mathrm{C}_{19} \mathrm{H}_{13} \mathrm{~N}_{5}(311.3): \mathrm{C}, 73.30 ; \mathrm{H}, 4.21 ; \mathrm{N}$, 22.49. Found: C, 73.09; H, 4.17; N, 22.19.

7-Ethyl-3-methyl-3,7-dihydroimidazo[4,5-a]quinindoline-12-carbonitrile (3b): compound $\mathbf{3 b}$ was obtained as shiny yellow needles $(\mathrm{EtOH})$, yield $74 \%, \mathrm{mp} 342-345{ }^{\circ} \mathrm{C} ;{ }^{1} \mathrm{H}$ NMR $\left(\mathrm{CDCl}_{3}\right) \delta$ $1.51(\mathrm{t}, J 7.2 \mathrm{~Hz}, 3 \mathrm{H}), 4.28(\mathrm{~s}, 3 \mathrm{H}), 4.33$ (q, J 7.2 Hz, 2H), 7.45 (td, $\left.J_{1} 8.0 \mathrm{~Hz}, J_{2} 0.8 \mathrm{~Hz}, 1 \mathrm{H}\right)$, $7.56(\mathrm{~d}, J 8.4 \mathrm{~Hz}, 1 \mathrm{H}), 7.72\left(\mathrm{td}, J_{1} 8.0 \mathrm{~Hz}, J_{2} 1.2 \mathrm{~Hz}, 1 \mathrm{H}\right), 7.88(\mathrm{~d}, J 9.2 \mathrm{~Hz}, 1 \mathrm{H}), 8.10(\mathrm{~d}, J 9.2$ $\mathrm{Hz}, 1 \mathrm{H}), 8.21(\mathrm{~s}, 1 \mathrm{H}), 8.96(\mathrm{~d}, J 8.0 \mathrm{~Hz}, 1 \mathrm{H}) \mathrm{ppm} ;{ }^{13} \mathrm{C} \mathrm{NMR}\left(\mathrm{CDCl}_{3}\right): \delta 13.8,31.1,36.3,104.1$, 109.1, 113.1, 116.0, 117.7, 118.8, 119.1, 120.1, 124.1, 124.9, 129.6, 129.9, 137.9, 141.4, 142.4, 144.1, 149.6 ppm; IR (KBr disk): $v 2223 \mathrm{~cm}^{-1}(\mathrm{CN})$. MS (m/z) $325\left(\mathrm{M}^{+}\right)$. Anal. Calcd for $\mathrm{C}_{20} \mathrm{H}_{15} \mathrm{~N}_{5}$ (325.4): C, 73.83; H, 4.65; N, 21.52. Found: C, 73.60; H, 4.61; N, 21.39.

7-Methyl-3-propyl-3,7-dihydroimidazo[4,5-a]quinindoline-12-carbonitrile (3c): compound 3c was obtained as shiny yellow needles $(\mathrm{EtOH})$, yield $70 \%$, mp 303-305 ${ }^{\circ} \mathrm{C} ;{ }^{1} \mathrm{H} \mathrm{NMR}\left(\mathrm{CDCl}_{3}\right)$ $\delta 1.03(\mathrm{t}, J 7.2 \mathrm{~Hz}, 3 \mathrm{H}), 1.98-2.08(\mathrm{~m}, 2 \mathrm{H}), 4.09$ (s, 3H), 4.35 (q, J 7.2 Hz, 2H), $7.44\left(\mathrm{td}, J_{1} 8.0\right.$ $\left.\mathrm{Hz}, J_{2} 0.8 \mathrm{~Hz}, 1 \mathrm{H}\right), 7.53(\mathrm{~d}, J 8.4 \mathrm{~Hz}, 1 \mathrm{H}), 7.73\left(\mathrm{td}, J_{1} 8.0 \mathrm{~Hz}, J_{2} 1.2 \mathrm{~Hz}, 1 \mathrm{H}\right), 7.87$ (d, J 9.2 Hz, $1 \mathrm{H}), 8.12(\mathrm{~d}, J 9.2 \mathrm{~Hz}, 1 \mathrm{H}), 8.23(\mathrm{~s}, 1 \mathrm{H}), 8.92(\mathrm{~d}, J 8.0 \mathrm{~Hz}, 1 \mathrm{H}) \mathrm{ppm} ;{ }^{13} \mathrm{C} \mathrm{NMR}\left(\mathrm{CDCl}_{3}\right): \delta 11.3$, 23.6, 35.1, 47.1, 104.2, 109.0, 113.7, 115.8, 117.8, 118.7, 119.2, 120.23, 124.1, 124.9, 129.6, 129.9, 138.0, 141.6, 142.4, 144.1, 149.6 ppm; IR (KBr disk): v $2225 \mathrm{~cm}^{-1}$ (CN). MS (m/z) 339 $\left(\mathrm{M}^{+}\right.$). Anal. Calcd for $\mathrm{C}_{21} \mathrm{H}_{17} \mathrm{~N}_{5}$ (339.4): C, 74.32; H, 5.05; N, 20.63. Found: C, 74.02; H, 4.99; N, 20.34 .

7-Ethyl-3-propyl-3,7-dihydroimidazo[4,5-a]quinindoline-12-carbonitrile (3d): compound 3d was obtained as shiny yellow needles $(\mathrm{EtOH})$, yield $75 \%$, mp 305-306 ${ }^{\circ} \mathrm{C} ;{ }^{1} \mathrm{H} \mathrm{NMR}\left(\mathrm{CDCl}_{3}\right) \delta$ 1.05 (t, J 7.2 Hz, 3H), 1.57 (t, J 7.2 Hz, 3H), 2.00-2.09 (m, J 7.2 Hz, 2H), 4.35 (t, J 7.2 Hz, 2H), 4.69 (q, J 7.2 Hz, 2H), 7.43 (td, $\left.J_{1} 8.0 \mathrm{~Hz}, J_{2} 0.8 \mathrm{~Hz}, 1 \mathrm{H}\right), 7.55$ (d, J 8.4 Hz, 1H), 7.72 (td, $J_{1} 8.0$ $\left.\mathrm{Hz}, J_{2} 1.2 \mathrm{~Hz}, 1 \mathrm{H}\right), 7.87(\mathrm{~d}, J 9.2 \mathrm{~Hz}, 1 \mathrm{H}), 8.11(\mathrm{~d}, J 9.2 \mathrm{~Hz}, 1 \mathrm{H}), 8.21(\mathrm{~s}, 1 \mathrm{H}), 8.95(\mathrm{~d}, J 8.0 \mathrm{~Hz}$, 1H) ppm; ${ }^{13} \mathrm{C}$ NMR $\left(\mathrm{CDCl}_{3}\right): \delta 11.4,13.8,23.8,36.4,47.1,104.1,109.0,113.7,115.9,117.8$, 118.7, 119.4, 120.5, 124.0, 124.4, 129.5, 129.8, 138.1, 141.6, 142.4, 144.1, 149.7 ppm; IR (KBr disk): $v 2225 \mathrm{~cm}^{-1}(\mathrm{CN})$. MS (m/z) $353\left(\mathrm{M}^{+}\right)$. Anal. Calcd for $\mathrm{C}_{22} \mathrm{H}_{19} \mathrm{~N}_{5}$ (353.4): C, 74.77; H, 5.42; N, 19.82. Found: C, 75.01; H, 5.47; N, 19.61 . 


\section{References}

1. Hunger, K., Industrial Dyes, Wiley-VCH, Weinheim, 2003, pp. 569-572.

2. Dmitry, A.; Pavel, A. Chem. Commun. 2003, 1394.

3. Gold, H., The Chemistry of Synthetic Dyes, ed. Venkataraman K.; Academic Press, New York, 1971, pp. 535-542.

4. Belgodere, E.; Bossio, R.; Chimichi, S.; Passini, V.; Pepino, R. Dyes Pigm. 1985, 4, 59. http://dx.doi.org/10.1016/0143-7208(83)80007-2

5. Kalle, A. G., British Patent, 1962, 895,001.

6. Fridman, N.; Kaftory, M.; Speiser, S. Sens. Actuators B 2007, 126, 107. http://dx.doi.org/10.1016/j.snb.2006.10.066

7. Karolak-Wojciechowska, J.; Mrozek, A.; Czylkowski, R.; Tekiner-Gulbas, B.; Ak1-Sener, E.; Yalcin, I. J. Mol. Struct. 2007, 839, 125. http://dx.doi.org/10.1016/j.molstruc.2006.11.023

8. Pan, W. L.; Tan, H. B.; Chen, Y.; Mu, D. H.; Liu, H. B.; Wan, Y. Q.; Song, H. C. Dyes Pigm. 2008, 76, 17.

http://dx.doi.org/10.1016/j.dyepig.2006.07.034

9. Um, S. I. Dyes Pigm. 2007, 75, 185.

http://dx.doi.org/10.1016/j.dyepig.2006.04.024

10. Molina, A.; Vaquero, J. J.; Garcia-Navio, J. L.; Alvarez-Builla, J.; de Pascual-Teresa, B.; Gago, F.; Rodrigo, M. M.; Ballesteros, M. J. Org. Chem., 1996, 61, 5587.

http://dx.doi.org/10.1021/j0960266h

11. Cimanga, K.; De Bruyne, T.; Pieters, L.; Vlietinck, A. J.; Turger, C. A. J. Nat. Prod. 1997, 60,688 .

http://dx.doi.org/10.1021/np9605246

12. Paulo, A.; Gomes, E. T.; Steele, J.; Warhurst, D. C.; Houghton, P. J. Planta Med. 2000, 66, 30.

http://dx.doi.org/10.1055/s-2000-11106

13. Miert, S. V.; Hostyn, S.; Maes, B. U. M.; Cimanga, K.; Brun, R.; Kaiser, M.; Matyus, P.;

Dommisse, R.; Lemiere, G.; Vlietinck, A.; Pieters, L. J. Nat. Prod., 2005, 68, 674.

http://dx.doi.org/10.1021/np0496284

14. Cimanga, K.; DeBruyne, T.; Lasure, A.; Poel, B. V.; Pieters, L.; Claeys, M.; Berghe, D. V.; Vlietinck, A. J. Planta Med., 1996, 62, 22. http://dx.doi.org/10.1055/s-2006-957789

15. Bierer, D. E.; Fort, D. M.; Mendez, C. D.; Luo, J.; Imbach, P. A.; Dubenko, L. G.; Jolad, S. D.; Gerber, R. E.; Litvak, J.; Lu, Q.; Zhang, P.; Reed, M. J.; Waldeck, N.; Bruening, R. C.; Noamesi, B. K.; Hector, R. F.; Carlson, T. J.; King, S. R. J. Med. Chem., 1998, 41, 894. http://dx.doi.org/10.1021/jm9704816

16. Abblordeppey, S. Y.; Fan, P.; Clark, A. M.; Nimrod, A. Bioorg. Med. Chem. 1999, 7,343. http://dx.doi.org/10.1016/S0968-0896(98)00244-2 
17. Rahimizadeh, M.; Pordel, M.; Bakavoli, M.; Eshghi, H. Dyes Pigm. 2010, 86, 266. http://dx.doi.org/10.1016/j.dyepig.2010.01.013

18. Sahraei, R.; Pordel, M.; Behmadi, H.; Razavi, B. J. Lumin. 2013, 136, 334. http://dx.doi.org/10.1016/j.jlumin.2012.12.024

19. Pakjoo, V.; Roshani, M.; Pordel, M.; Hoseini, T. Arkivoc 2012, (ix), 195. http://dx.doi.org/10.3998/ark.5550190.0013.917

20. Pordel, M. J. Chem. Res. 2012, 36, 595. http://dx.doi.org/10.3184/174751912X13459948434388

21. Rahimizadeh, M.; Pordel, M.; Ranaei, M.; Bakavoli, M. J. Heterocyclic Chem. 2012, 49, 208. http://dx.doi.org/10.1002/jhet.681

22. Hoseini-Hesar, T.; Pordel, M.; Roshani, M.; Shams, A. J. Chem. Res. 2013, 438.

23. Pordel, M.; Beyramabadi, S. A.; Mohammadinejad, A. Dyes Pigm. 2014, 102, 46. http://dx.doi.org/10.1016/j.dyepig.2013.10.021

24. Davis, R. B.; Pizzini, L. C. J. Org. Chem. 1960, 25, 1884. http://dx.doi.org/10.1021/jo01081a015

25. Mąkosza, M.; Wojciechowski, K. Chem. Rev. 2004, 104, 2631. http://dx.doi.org/10.1021/cr020086+

26. Umberger, J. Q.; LaMer, V. K. J. Am. Chem. Soc. 1945, 67, 1099. http://dx.doi.org/10.1021/ja01223a023

27. Dal, H.; Süzen, Y.; Şahin, E. Spectrochim. Acta Part A 2007, 67, 808. http://dx.doi.org/10.1016/j.saa.2006.08.037

28. Aliprandi, B.; Cacace, F.; Possagno, E. Ann. Chim. (Italy) 1958, 48, 1349.

29. Potts, K. T.; Saxton, J. E. Org. Synth. 1973, 5, 769.

30. Snyder, H. R.; Eliel, E. L.; J. Am. Chem. Soc. 1948, 70,1703. http://dx.doi.org/10.1021/ja01185a009

31. Frisch, M. J.; Trucks, G.W.; Schlegel, H. B.; Scuseria, G. E.; Robb, M. A.; Cheeseman, J. R.; Zakrzewski, V. G.; Montgomery, J. A.; Stratmann, R. E.; Burant, J. C.; Dapprich, S.; Millam, J. M.; Daniels, A. D.; Kudin, K. N.; Strain, M. C.; Farkas, O.; Tomasi, J.; Barone, V.; Cossi, M.; Cammi, R.; Mennucci, B.; Pomelli, C.; Adamo, C.; Clifford, S.; Ochterski, J.; Petersson, G.A.; Ayala, P.Y.; Cui, Q.; Morokuma, K.; Malick, D. K.; Rabuck, A. D.; Raghavachari, K.; Foresman, J. B.; Cioslowski, J.; Ortiz, J. V.; Stefanov, B. B.; Liu, G.; Liashenko, A.; Piskorz, P.; Komaromi, I.; Gomperts, R.; Martin, R. L.; Fox, D. J.; Keith, T.; Al-Laham, M. A.; Peng, C. Y.; Nanayakkara, A.; Gonzalez, C.; Challacombe, M.; Gill, P. M. W.; Johnson, B. G.; Chen, W.; Wong, M. W.; Andres, J. L.; Head-Gordon, M.; Replogle, E. S.; Pople, J. A. Gaussian 98, Revision A.7; Gaussian, Inc.: Pittsburgh PA, 1998.

32. Lee, C.; Yang, W.; Parr, R. G. Phys. Rev. B 1988, 37, 785. http://dx.doi.org/10.1103/PhysRevB.37.785

33. Tomasi, J.; Cammi, R. J. Comput. Chem. 1995; 16, 1449. http://dx.doi.org/10.1002/jcc.540161202 
34. Ditchfield, R. Mol. Phys. 1974, 27, 789.

http://dx.doi.org/10.1080/00268977400100711 